\title{
DIGE analysis of rat skeletal muscle proteins using nonionic detergent phase extraction of young adult versus aged gastrocnemius tissue
}

\author{
Pamela Donoghue ${ }^{a, 1}$, Lisa Staunton ${ }^{b, 1}$, Edel Mullen ${ }^{b}$, Gwen Manning $^{a}$, Kay Ohlendieck ${ }^{b, *}$ \\ ${ }^{a}$ Conway Institute, University College Dublin, Belfield, Dublin 4, Ireland \\ ${ }^{\mathrm{b}}$ Department of Biology, National University of Ireland, Maynooth, Co. Kildare, Ireland
}

\section{A R T I C L E I N F O}

Keywords:

Aging

Detergent phase extraction

DIGE

Muscle proteomics

Sarcopenia

\begin{abstract}
A B S T R A C T
Contractile weakness and loss of muscle mass are critical features of the aging process in mammalians. Age-related fibre wasting has a profound effect on muscle metabolism, fibre type distribution and the overall physiological integrity of the neuromuscular system. This study has used mass spectrometry-based proteomics to investigate the fate of the aging rat muscle proteome. Using nonionic detergent phase extraction, this report shows that the aged gastrocnemius muscle exhibits a generally perturbed protein expression pattern in both the detergent-extracted fraction and the aqueous protein complement from senescent muscle tissue. In the detergent-extracted fraction, the expression of ATP synthase, isocitrate dehydrogenase, enolase, tropomyosin and beta-actin was increased. Different isoforms of creatine kinase and prohibitin showed differential changes. In the aqueous fraction, malate dehydrogenase, sulfotransferase, triosephosphate isomerase, aldolase, cofilin-2 and lactate dehydrogenase showed increased levels. Interestingly, differential effects on dissimilar 2-D spots of the same protein species were shown for $\mathrm{Cu} / \mathrm{Zn}$ superoxide dismutase, albumin, annexin A4 and phosphoglycolate phosphatase. Mitochondrial Hsp60, Hsp71 and nucleoside diphosphate kinase $B$ exhibited a reduced abundance in aged muscle. The majority of altered proteins were found to be involved in mitochondrial metabolism, glycolysis, metabolic transportation, regulatory processes, the cellular stress response, detoxification mechanisms and muscle contraction.
\end{abstract}

(C) 2010 Elsevier B.V. All rights reserved.

\section{Introduction}

Natural aging is a fundamental biological process [1], whereby one of the most striking features of the senescent body is the loss in muscle mass and function [2]. Age-related contractile weakness has been termed sarcopenia of old age and is probably indirectly involved in many physiological and metabolic alterations in the aging organism [3-5]. Denervation probably plays a key role in the age-dependent shift to a slower-twitching phenotype [6]. Although longitudinal studies indicate that contractile function may be preserved in single human muscle fibres [7], it has clearly been established that significant alterations occur at the whole-muscle level [8]. The age-related reduction in cross-sectional muscle area

\footnotetext{
* Corresponding author. Tel.: +353 1708 3842; fax: +353 17083845 .

E-mail address: kay.ohlendieck@nuim.ie (K. Ohlendieck).

${ }^{1}$ Both authors contributed equally to this body of work.
} 
correlates relatively well with the decreased specific force of senescent muscles [9]. A variety of cross-sectional studies agree that the tissue mass of the aged musculature decreases dramatically. It is estimated that 15 to $42 \%$ of muscle mass is lost between the ages of 20 and 80 [10-12].

Several mass spectrometry-based proteomic studies have investigated changes in the protein complement of aging skeletal muscles over the last few years, as reviewed by Doran et al. [13]. These proteomic profiling studies have focused on crude soluble extracts and have shown that muscle aging is associated with altered expression levels of many key contractile proteins, regulatory elements, ion handling proteins, metabolic enzymes and mediators of the cellular stress response [14-20]. The proteomic finding of a drastically decreased density and reduced enzymatic activity of certain glycolytic enzymes in senescent fibres [21] is in agreement with the idea of a fast-to-slow transformation process during aging [13]. In analogy, proteomic surveys clearly revealed increased levels of mitochondrial enzymes and metabolite transporters of aerobic metabolism in aged muscle [22]. Thus, fibre shifting to slower twitch characteristics with a more oxidative bioenergetic profile appears to occur in the aging neuromuscular system. Recently, comparative subproteomics of the soluble myofibril-enriched fraction has shown distinct age-dependent effects on the contractile apparatus. The contractile protein exhibiting the most drastically changed expression was identified as the MLC2 isoform of the slowtype myosin light chain [23], which also exhibits enhanced phosphorylation levels in aged fibres [24]. Although fast and slow isoforms of myosin heavy chain switch in the majority of aged fibres, the dramatic increase in slow MLC2 expression was restricted to individual senescent cells [23]. Since posttranslational modifications play a central role in protein function and considerably increase protein diversity within the skeletal muscle proteome, it is important to stress that glycosylation, tyrosine nitration, and tyrosine/threonine phosphorylation are generally altered in senescent skeletal muscles [21,24,25], thereby complicating global protein expression analysis.

Building on the proteomic findings from the above described surveys of total crude muscle extracts [13], this study has focused on the proteomic profiling of senescent muscle tissue with respect to the aqueous versus the detergent-extracted fraction. Nonionic detergent phase extraction was carried out with Triton X-114. This detergent is ideal for the phase partitioning of soluble and membrane-associated muscle proteins, as fractionated proteins are not degraded or excessively denatured [26,27]. The method was previously validated in cardiac tissue and resulted in two distinct subproteomes by partitioning soluble and membrane-associated proteins into aqueous and detergent phases, respectively [27]. Here, 2-D fluorescence DIGE analysis [28] was used to compare the young adult versus the senescent rat gastrocnemius muscle. Following the gel electrophoretic separation of the aqueous and the detergent-extracted fraction from skeletal muscle homogenates, proteins of interest with a changed abundance were identified by MALDI-ToF MS, MALDI-ToF/ToF MS and ESI LC-MS/ MS technology. Several new potential markers of muscle aging were identified which might be useful for the future establishment of a comprehensive biomarker signature of sarcopenia.

\section{Materials and methods}

\subsection{Materials}

CyDye DIGE Fluor minimal dyes Cy3 and Cy5, ampholytes, cover fluid, acetonitrile, the Plus-One silver-staining kit, and immobilised $\mathrm{pH}$ gradient (IPG) drystrips for 2-DE were obtained from Amersham Bioscience/GE Healthcare (Little Chalfont, Bucks, UK). Sequencing grade-modified trypsin was purchased from Promega (Madison, WI, USA). LC-MS Chromasolv water and formic acid were from Fluka (Milwaukee, WI, USA). Acrylamide stock solutions were purchased from National Diagnostics (Atlanta, GA, USA). GE buffer systems, protein molecular weight ladders and Bradford reagent were obtained from Biorad Laboratories (Hemel-Hempstead, Herts., UK). Protease inhibitors were from Roche Diagnostics (Mannheim, Germany). Nitrocellulose transfer stacks were obtained from Invitrogen (Carlsbad, CA, USA). Chemiluminescence substrate was purchased from Roche Diagnostics (Mannheim, Germany). Primary and secondary antibodies were obtained from various commercial sources, as listed in previous studies [16-18]. Ultrapure lysine for quenching the DIGE labeling reaction and all other analytical-grade chemicals were purchased from Sigma Chemical Company (Dorset, $\mathrm{UK})$.

\subsection{Nonionic detergent phase extraction of muscle proteins}

Fractionation of crude skeletal muscle tissue preparations into an aqueous phase and a detergent-extracted phase was carried out as previously described for cardiac muscle [27]. Freshly dissected gastrocnemius muscle tissue $(250 \mathrm{mg})$ from 3 Wistar rats each of 3-month and 26-month of age were ground into a fine powder under liquid nitrogen using a pestle and mortar. The age groups studied represent young adult animals versus senescent rats [16-18]. Ground tissue was immediately added to $8 \mathrm{ml}$ of ice-cold phosphate buffered saline (PBS; $0.9 \%$ (w/v) NaCl, $50 \mathrm{mM}$ sodium phosphate, $\mathrm{pH} 7.4$ ) and $2 \mathrm{ml}$ of $10 \%(\mathrm{v} / \mathrm{v})$ Triton $\mathrm{X}-114$ and left overnight at $4{ }^{\circ} \mathrm{C}$ on a rotary shaker. The suspended samples were centrifuged at $20,000 \mathrm{~g}$ for $30 \mathrm{~min}$ at $4{ }^{\circ} \mathrm{C}$ to remove tissue debris. The supernatant was incubated for $30 \mathrm{~min}$ at $37^{\circ} \mathrm{C}$ and then centrifuged for $5000 \mathrm{~g}$ at $25^{\circ} \mathrm{C}$ to separate detergent and aqueous phases. The aqueous top layer was removed to a fresh $50 \mathrm{ml}$ tube to which $2 \mathrm{ml}$ of $10 \%(\mathrm{v} / \mathrm{v})$ Triton X-114 was added. The lower detergent-extracted phase was resuspended in $8 \mathrm{ml}$ of ice-cold PBS. Both samples were placed for $15 \mathrm{~min}$ at $37^{\circ} \mathrm{C}$, followed by a $15 \mathrm{~min}$ centrifuge spin at $5000 \mathrm{~g}$ and $25^{\circ} \mathrm{C}$. This process was repeated 3 times in order to wash each fraction and remove potential cross-contaminants. Differently separated proteins were extracted from each phase by acetone precipitation at $-20^{\circ} \mathrm{C}$ for $1 \mathrm{~h}$. Following a centrifugation step at $5000 \mathrm{~g}$ for $30 \mathrm{~min}$, precipitated proteins were resuspended in $1 \mathrm{ml}$ buffer and $200 \mu \mathrm{l}$ of DIGE-compatible lysis buffer [18]. The total protein yield from starting material of $250 \mathrm{mg}$ of skeletal muscle tissue was $5.16 \pm 0.38 \mathrm{mg}$ in the young AQ phase $(n=5), 4.78 \pm 0.62 \mathrm{mg}$ in the old AQ phase $(n=5), 0.45 \pm$ $0.10 \mathrm{mg}$ in the young DT phase $(n=5)$ and $0.40 \pm 0.09 \mathrm{mg}$ in the 
old DT phase $(n=5)$. Protein concentration was determined by the Bradford dye-binding assay [29].

\subsection{Gel electrophoretic analysis}

For the comparative proteomic analysis of proteins fractionated into AQ phase and DT phase, minimal fluorescent dye labeling was performed at a ratio of $25 \mu \mathrm{g}$ of protein per $200 \mathrm{pmol}$ of CyDye as previously described [30], following the recommendations of Karp and co-workers for optimized DIGE analysis [31,32]. Labeled samples were incubated on ice for $30 \mathrm{~min}$ in the dark. The labeling reaction was terminated by the addition of $10 \mathrm{mM}$ lysine [18]. Labeled protein extracts were utilized immediately for further analysis or otherwise stored at $-80^{\circ} \mathrm{C}$. Protein samples, for separation over a $\mathrm{pH}$ 4-7 gradient, were combined with an equal volume of $2 \times$ lysis buffer $(9.5 \mathrm{M}$ urea, $2 \%(\mathrm{w} / \mathrm{v})$ CHAPS, $2 \%$ (w/v) DTT and 1.6\% Pharmalyte pH 3-10), followed by in-gel rehydration overnight prior to isoelectric focusing. A final strip volume of $450 \mu \mathrm{l}$ was achieved through the addition of rehydration buffer (8 M urea, 0.5\% (w/v) CHAPS, 0.2\% (w/v) DTT and $0.2 \% \mathrm{w} / \mathrm{v}$ Pharmalyte $\mathrm{pH} 3-10)$. First dimension gel electrophoretic separation was performed at $0.05 \mathrm{~mA} / \mathrm{IPG}$ strip for $75.000 \mathrm{Vh}$, using $8000 \mathrm{~V}$ for $10 \mathrm{~min}$ and $8000 \mathrm{~V}$ for $1 \mathrm{~h}$ at $20^{\circ} \mathrm{C}$. Basic IPGphor strips (18 cm pH 6-11) were prehyrated in $300 \mu \mathrm{l}$ basic rehydration buffer ( $8 \mathrm{M}$ urea, $0.5 \%(\mathrm{w} / \mathrm{v})$ CHAPS, $0.2 \%(\mathrm{w} / \mathrm{v})$ DTT and 1.2\% DeStreak Reagent) overnight at room temperature. Protein samples, for separation over a $\mathrm{pH}$ 6-11 gradient, were combined with an equal volume of $2 \times$ lysis buffer $(9.5 \mathrm{M}$ urea, 2\% (w/v) CHAPS, 2\% (w/v) DTT and 1.2\% DeStreak Reagent). Final sample volume was brought up to $100 \mu \mathrm{l}$ in basic rehydration buffer and actively paper bridge loaded onto $\mathrm{pH}$ 6-11 IPG strips for $16 \mathrm{~h}$ at $200 \mathrm{~V}$ [33]. Following active paper bridge sample loading, all wicks were changed. IEF was performed at $0.05 \mathrm{~mA} / \mathrm{IPG}$ strip at $300 \mathrm{~V}$ for $2 \mathrm{~h}, 600 \mathrm{~V}$ for $2 \mathrm{~h}, 1000 \mathrm{~V}$ for $1 \mathrm{~h}$, $8000 \mathrm{~V}$ for $1 \mathrm{~h}$ and finally $8000 \mathrm{~V}$ to achieve $50.000 \mathrm{Vh}$. All focused IPG strips were immediately used for the 2D separation step or frozen and stored at $-80^{\circ} \mathrm{C}$. Strip equilibration was carried out in $10 \mathrm{ml} /$ strip of equilibration buffer $(6 \mathrm{M}(\mathrm{w} / \mathrm{v})$ urea, $30 \%$ (v/v) glycerol, 2\% (w/v) SDS, $0.05 \mathrm{M}$ Tris-HCl, $\mathrm{pH} 8.8$ and $0.1 \%$ (w/v) bromophenol blue) with the addition of $1 \%(w / v)$ DTT for $15 \mathrm{~min}$. Subsequently $5 \%$ (w/v) iodoacetamide was added to the above equilibration buffer with strip incubation for a further $15 \mathrm{~min}$. 2-D separation was carried out at $1 \mathrm{~W} /$ gel for approx $24 \mathrm{~h}$ using a Protean Plus Dodeca cell system (Biorad Laboratories (Hemel-Hempstead, Herts., UK) at $15^{\circ} \mathrm{C}$ and was terminated when the dye front had just migrated off the lower end of the gels. A total of 24 gels were analyzed over $\mathrm{pH} 4-7$ and $\mathrm{pH}$ 6-11 ranges. This covered both young adult and aged gastrocnemius specimens with respect to AQ- and DT-phase-enriched proteins. Gels were scanned using a Typhoon variable mode imager 9400 (Amersham Bioscience/GE Healthcare, Little Chalfont, Bucks, UK), with a standard pixel volume of $60 \mathrm{~K}-80 \mathrm{~K}$ for all scans. The isolation of crude extracts from skeletal muscle tissue, 1-D gel electrophoresis, and silver staining of 1D or 2D gels was carried out as previously described in detail [22].

\subsection{Expression analysis}

Following nonionic detergent phase extraction of muscle proteins, DIGE labeling and 2-DE separation, protein expres- sion changes between young adult and aged samples from the AQ and DT fractions were analyzed using Progenesis SameSpots analysis software from Non Linear Dynamics (Newcastle upon Tyne, UK). Prior to analysis, individual gels were warped to a single master gel and further matched and normalized with non-gel spots manually filtered out on the basis of spot volume. SameSpots analysis (SSA) was used to identify proteins of interest using the following parameters: $n=5$; ANOVA $p<0.05$; t-test $p<0.05$; and a power value of $>0.8$. Proteins with a significantly changed abundance were picked for tryptic digestion from silver-stained preparative gels.

\subsection{Protein digestion}

Excised protein spots from 2-DE gels were added to $200 \mathrm{mM}$ ammonium bicarbonate solution and incubated at $37^{\circ} \mathrm{C}$ for 10 min with gentle agitation. Following a brief spin, a solution of $200 \mathrm{mM}$ ammonium bicarbonate/acetonitrile 2:3 was added to each gel plug and left at $37^{\circ} \mathrm{C}$ for $10 \mathrm{~min}$ with gentle agitation. Samples were spun again briefly and resuspended in $50 \mathrm{mM}$ ammonium bicarbonate and left at $37^{\circ} \mathrm{C}$ for $10 \mathrm{~min}$ with gentle agitation. Gel plugs were shrunk using $100 \%$ acetonitrile for $10 \mathrm{~min}$ at $37^{\circ} \mathrm{C}$. Proteins were digested overnight at $37^{\circ} \mathrm{C}$ with gentle agitation using $0.2 \mathrm{ng} /$ $\mu \mathrm{l}$ of sequence grade-modified trypsin (Promega, Madison, WI, USA). Peptides were recovered by removing supernatants from digested gel plugs. Further recovery was achieved by adding $30 \%$ acetonitrile/ $0.2 \%$ trifluoric acid to the gel plugs for $10 \mathrm{~min}$ at $37^{\circ} \mathrm{C}$ with gentle agitation. Following a brief spin, supernatants were added to the initial peptide recovery following digestion. Exhaustive peptide recovery was achieved through the addition of $60 \%$ acetonitrile/ $0.2 \%$ trifluoric acid to each plug for $10 \mathrm{~min}$ at $37^{\circ} \mathrm{C}$ with gentle agitation. Supernatants were added to the peptide pool. Sample volume was reduced until dry through vacuum centrifugation. Samples were resuspended in $30 \mu \mathrm{l}$ of ultrapure $\mathrm{ddH}_{2} \mathrm{O}$ and $0.1 \%$ formic acid for identification by mass spectrometry.

\subsection{ESI LC-MS/MS analysis}

ESI LC-MS/MS analysis was carried out in the Proteomics Suite of the National University of Ireland, Maynooth. Nanoflow LC separation of tryptic peptides was performed with a nanoflow 1200 series system from Agilent Technologies (Santa Clara, CA, USA), equipped with a Zorbax 300SB C18 $5 \mu \mathrm{m}, 4 \mathrm{~mm} 40 \mathrm{nl}$ pre-column and an Zorbax 300SB C18 $5 \mu \mathrm{m}, 43 \mathrm{~mm} \times 75 \mu \mathrm{m}$ analytical reversed phase column using HPLC-Chip technology. Samples were initially transferred with an aqueous $0.1 \%$ formic acid solution to a precolumn with a flow rate of $4 \mu \mathrm{l} / \mathrm{min}$ for $3 \mathrm{~min}$. Mobile phase A was $0.1 \%$ formic acid and mobile phase B $0.1 \%$ formic acid in acetonitrile. Peptides were separated with a gradient of 3 to $40 \%$ mobile phase B over $40 \mathrm{~min}$ at a flow rate of $400 \mu \mathrm{l} / \mathrm{min}$, followed by a $10 \mathrm{~min}$ wash with $90 \%$ of mobile phase $\mathrm{B}$. The column was re-equilibrated at initial conditions for $10 \mathrm{~min}$. Injection volume of $20 \mu \mathrm{l}$ was used per sample. Analysis of tryptic peptides was performed using an Agilent 6300 series ion trap LC mass spectrometer. All analyses were performed using 
positive nano-electrospray ion mode. The MS survey scan was set between 100 and $2200 \mathrm{~m} / \mathrm{z}$ with a duration of $0.5 \mathrm{~s} /$ scan and the 3 most intense peptides further selected for MS analysis. Collision energy was ramped between 1500 and $4500 \mathrm{~V}$ based on the observed precursor mass over charge value and charge state. Spectra were processed and analyzed by Spectrum Mill database search software (Agilent Technologies, Santa Barbara, CA).

\subsection{MALDI-ToF/ToF MS analysis}

MALDI-ToF MS analysis was performed in the Proteome Research Centre of the Conway Institute, University College Dublin. MALDI-ToF and MALDI-ToF/ToF mass spectrometric analyses were carried out with a 4800 plus MALDI ToF/ToF Analyzer (Applied Biosystems, Foster City, CA). Peptide masses were acquired over a range from 800 to $4000 \mathrm{~m} / \mathrm{z}$, with a focus mass of $2000 \mathrm{~m} / \mathrm{z}$. MS spectra were summed from 2500 laser shots from an Nd:YAG laser operating at $355 \mathrm{~nm}$ and $200 \mathrm{~Hz}$. Calibration was performed using peptide standards (masses 900-2400 m/z; Applied Biosystems). A maximum of 12 precursors per sample well with a signal-to-noise ratio of $>20$ were automatically selected for subsequent fragmentation by collision induced dissociation. MS/MS spectra were summed from 2000 laser shots. Spectra were processed and analyzed by the Global Protein Server Workstation (Applied Biosystems).

\subsection{Immunoblot analysis}

Immunodecoration of proteins of interest was carried out by 1-D immunoblot analysis as previously described in detail [17]. Following the electrophoretic transfer of proteins to nitrocellulose membranes, sheets were blocked in a milk protein solution for $1 \mathrm{~h}$ and then incubated overnight with gentle agitation with primary antibody, sufficiently diluted in blocking solution containing $5 \%(\mathrm{w} / \mathrm{v})$ fat-free milk powder in phosphate buffered saline (PBS; $0.9 \%$ (w/v) NaCl, $50 \mathrm{mM}$ sodium phosphate, $\mathrm{pH}$ 7.4). Primary antibodies were obtained from Affinity Bioreagents, Golden, CO, USA (mAb MA3-912 to the fast SERCA1 isoform of the sarcoplasmic reticulum $\mathrm{Ca}^{2+}$. ATPase; and mAb MA3-913 to the fast CSQf isoform of calsequestrin), StressGen Bioreagents, Victoria, Canada (pAb SPA-801 to heat shock protein Hsp25) and Abcam Ltd., Cambridge, UK (pAb ab28172 to the mitochondrial marker protein prohibitin; pAb ab48139 to succinate dehydrogenase, pAb ab34830 to malate dehydrogenase; and mAb ab14730 to mitochondrial ATP synthase). Subsequently, blots were washed twice with blocking solution for $10 \mathrm{~min}$ before incubation for $1 \mathrm{~h}$ with secondary peroxidase-conjugated antibodies, diluted in blocking solution. Secondary antibodies were purchased from Chemicon International (Temecula, CA, USA). Following further washing steps with blocking solution and then two rinsing steps with PBS, antibody-decorated bands were visualized by the enhanced chemiluminescence method following the manufacturer's recommendations (Roche Diagnostics, Mannheim, Germany). Densitometric scanning of immunoblots was performed on a Molecular Dynamics 300S computing densitometer (Sunnyvale, CA, USA) with Imagequant V3.0 software [22].

\section{Results}

3.1. Nonionic detergent phase extraction for the proteomic analysis of aged skeletal muscle

The subproteomic investigation described here is based on the principle of nonionic detergent phase extraction [26]. A comparison of the aqueous versus the detergent-extracted fraction from young adult versus senescent rat gastrocnemius muscle tissue was carried out. Fig. 1A outlines the experimental protocol used for the separation of skeletal muscle proteins by treatment with Triton X-114. Since phase separation with Triton X-114 occurs at temperatures above $22^{\circ} \mathrm{C}$, skeletal muscle protein fractionation was carried out at $37^{\circ} \mathrm{C}$ [27]. The separation step resulted in an aqueous AQ phaseenriched in hydrophilic proteins and a detergent DT phase with predominantly hydrophobic proteins. Despite repeated washing steps, phase transition approaches always result in a certain degree of cross-contamination between soluble and membrane-associated proteins. Extracted proteins were separated by standard 2-DE and proteins of interest identified by MS technology.

\subsection{Gel electrophoretic analysis of nonionic detergent phase extraction of muscle proteins}

Fig. 1B-E illustrates the successful enrichment of typical membrane-associated skeletal muscle proteins in the detergent-extracted fraction and a soluble enzyme in the aqueous phase-extracted fraction. The 1-DE analysis of crude preparations versus the aqueous phase versus the detergentextracted phase demonstrated the differing protein band pattern between the two main fractions following phase separation (Fig. 1B). Importantly, immunoblotting revealed a clear enrichment of the fast-twitch sarcoplasmic reticulum $\mathrm{Ca}^{2+}$-ATPase isoform SERCA1 (Fig. 1C) and the inner mitochondrial membrane-associated enzyme ATP synthase (Fig. 1E) in the detergent-extracted fraction from both young adult and aged muscle tissue. In stark contrast, the soluble isoform of cytosolic malate dehydrogenase (Fig. 1D) was found to be enriched in the aqueous phase from both young adult and aged muscle tissue. Following the initial evaluation of the nonionic detergent phase extraction method by 1-DE, the aqueous and detergent fractions were electrophoretically separated on large high-resolution 2-DE gels covering the $\mathrm{pH}$ 4-7 and pH 6-11 range in the first dimension. Fig. 2 gives an overview of the considerably different expression patterns of muscle proteins derived from the aqueous versus the detergent phase. Since silver staining exhibits a relatively limited dynamic range, the more discriminatory DIGE method was employed for a detailed determination of changes in protein abundance due to fibre aging.

\subsection{DIGE analysis of the aged muscle proteome}

Fluorescent DIGE is one of the most powerful biochemical tools for conducting comparative expression studies of complex proteomes, making it an ideal approach for a refined analysis of the detergent-enriched fraction from young adult 
A

Fresh skeletal muscle tissue
Young adult versus aged specimens

Liquid nitrogen

Pulverized tissue

\begin{tabular}{c|c}
$\begin{array}{c}\text { Triton } \mathrm{X}-114 \\
\text { in cold PBS }\end{array}$ & $\begin{array}{c}\text { Overnight } \\
\text { at } 4^{\circ} \mathrm{C}\end{array}$
\end{tabular}

Solubilized protein fraction

30 min spin \@ 20,000g

Supernatant fraction

Incubation at $\ 37^{\circ} \mathrm{C}$ for $30 \mathrm{~min}$

30 min spin @ 5000g

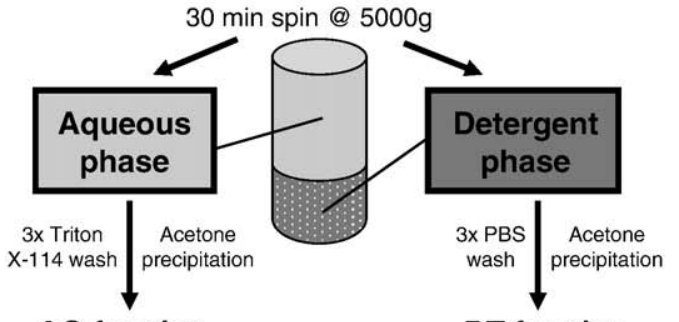

$A Q$ fraction

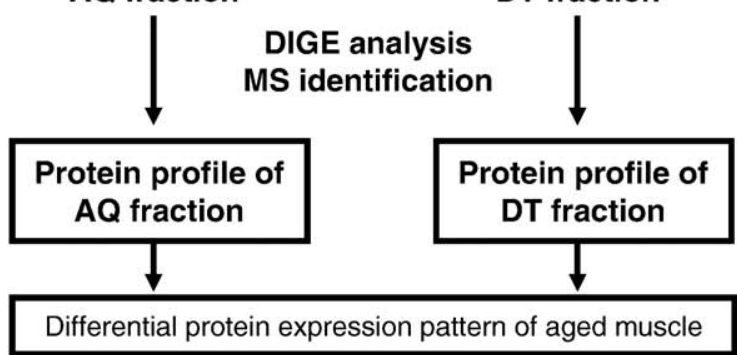

B

\section{D SDS-PAGE} MW YC OC YAQ OAQ YDT ODT
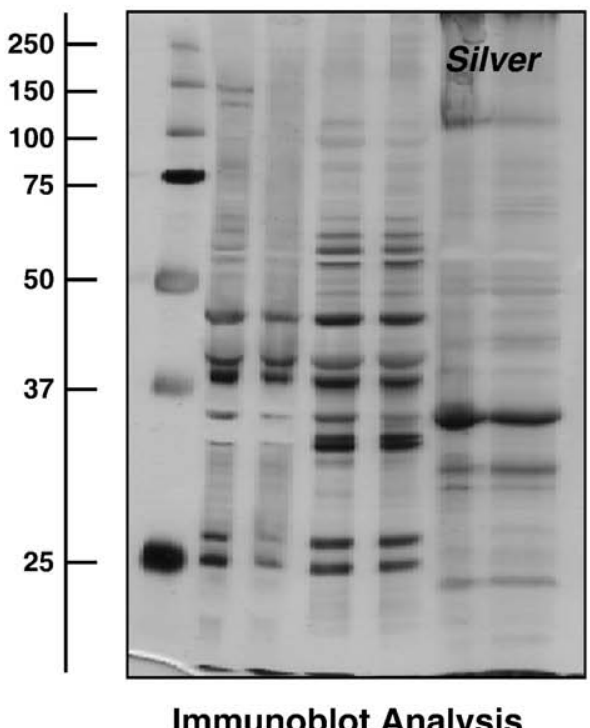

Immunoblot Analysis

C

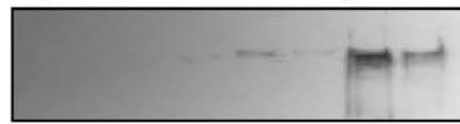

SER

CA1

D

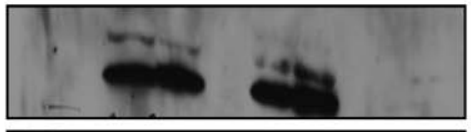

MDH

$\mathbf{E}$

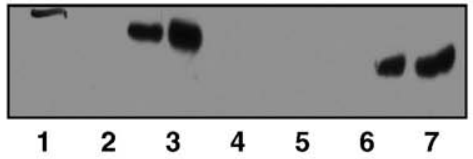

ATP

synthase

Fig. 1 - Nonionic detergent phase extraction of young adult versus old muscle tissue. The subcellular fractionation approach used in this subproteomic investigation is based on the principle of nonionic detergent phase extraction. The flowchart in panel (A) outlines the experimental protocol employed for the separation of skeletal muscle proteins by treatment with Triton $\mathrm{X}-114$. The temperature-dependent separation step resulted in an aqueous (AQ) phase-enriched in hydrophilic proteins and a detergent (DT) phase with predominantly hydrophobic proteins. Panel (B) shows a silver-stained 1-D SDS-PAGE gel of muscle protein fractions (100 $\mu \mathrm{g}$ of protein/gel lane) following nonionic detergent phase extraction. Lane 1 represents molecular weight markers (MW). Lanes 2 to 7 represent crude preparations from young muscle (YC), crude preparations from old muscle (OC), aqueous phase-enriched proteins from young muscle (YAQ), aqueous phase-enriched proteins from old muscle (OAQ), detergent phase-enriched proteins from young muscle (YDT) and detergent phase-enriched proteins from old muscle (ODT), respectively. Panels (C) to (E) show corresponding immunoblots labeled with antibodies to the integral SERCA1 isoform of the sarcoplasmic reticulum $\mathrm{Ca}^{2+}$-ATPase, the cytosolic isoform of malate dehydrogenase (MDH) and the mitochondrial enzyme ATP synthase, respectively. $30 \mu \mathrm{g}$ of protein was loaded per gel lane. The distinct subcellular fractionation of the integral versus soluble marker proteins during the detergent phase extraction procedures agrees with the idea of a successful separation of hydrophobic versus hydrophilic muscle proteins.

versus aged rat gastrocnemius muscle. It represents a highly accurate quantitative technique that enables multiple protein samples to be separated in parallel on the same 2-DE gel, thereby greatly reducing the introduction of potential artifacts due to gel-to-gel variations [28]. Following scanning with an Amersham Typhoon Trio variable imager and with the help of Progenesis 2-D analysis software, 94 protein species out of 2865 detectable 2-D spots were found to be differentially expressed. DIGE master gels representing electrophoretically separated proteins from young adult versus senescent muscle fibres are shown for the $\mathrm{pH} 4-7$ (Figs. 3A and 4A) and the $\mathrm{pH} 6-$ 11 (Figs. 3B and $4 \mathrm{~B}$ ) range. The lower and higher $\mathrm{pH}$-scale of the two different IEF approaches resulted in the separation of 657 and 371 protein spots in the detergent phase, and 1464 and 373 protein spots in the aqueous phase, respectively. The number of proteins that exhibited a changed abundance was 23, 15, 37 and 19 for the $\mathrm{pH}$ 4-7 DT phase, $\mathrm{pH}$ 6-11 DT phase, pH 4-7 AQ phase and pH 6-11 AQ phase, respectively. Proteins of interest were identified by mass spectrometry.

\subsection{Proteomic profile of aged skeletal muscle}

A list of DIGE-identified protein species with an altered concentration level in the DT-extracted and AQ fraction from 


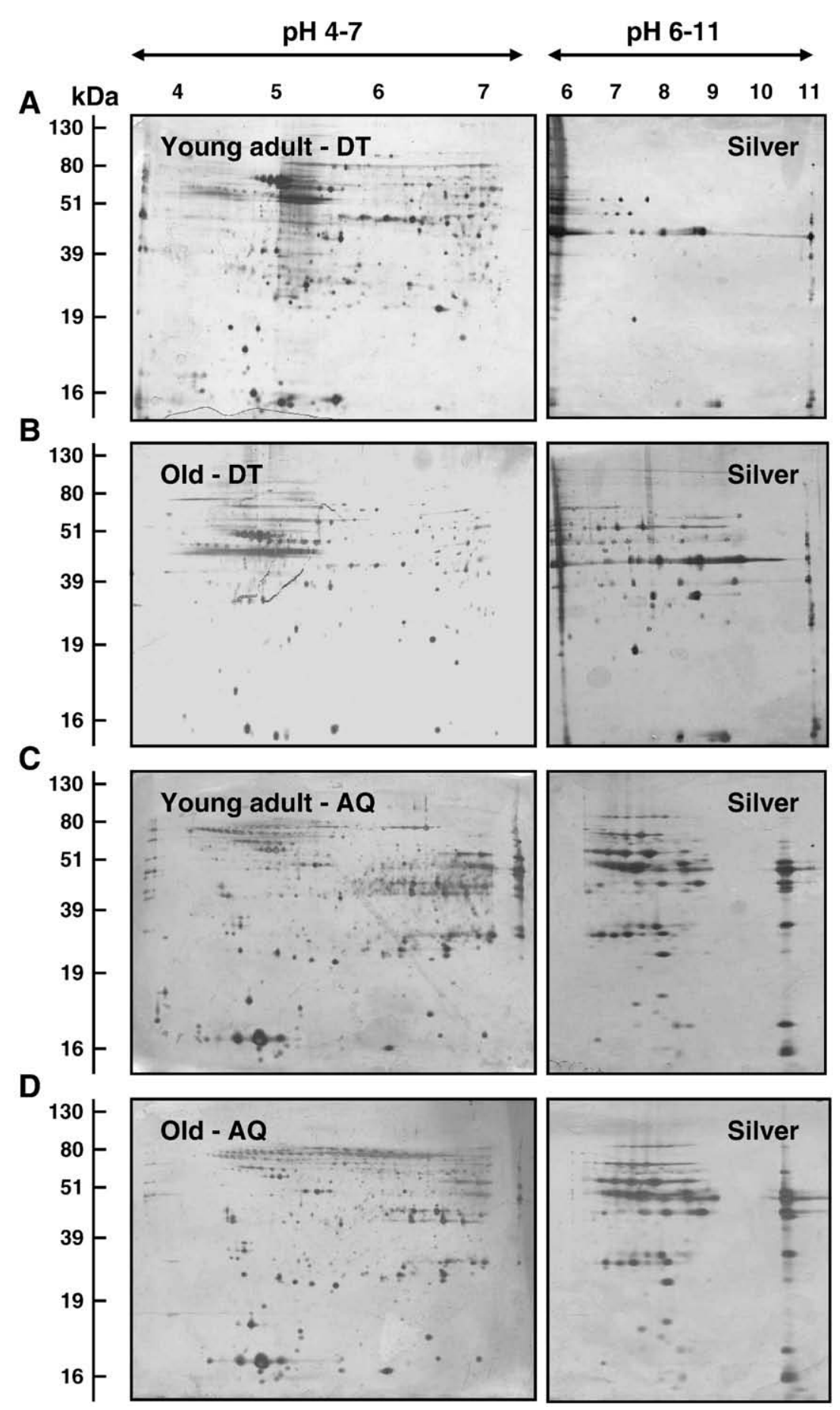

Fig. 2 - 2-DE analysis of young adult versus old skeletal muscle. Shown are silver-stained 2-DE gels of the detergent (DT; A, B) and aqueous (AQ; C, D) phase fractions from young adult (A, C) and old (B, D) rat skeletal muscle. Representative gels are shown for the pH 4-7 and pH 6-11 range. The pH values of the IEF system and molecular mass standards (in kDa) of the 2-DE gels are indicated on the top and on the left of the panels, respectively.

young adult versus aged rat gastrocnemius muscle is shown in Table 1. The table summarizes results with respect to the type of 2-DE gel used for protein separation, the type of MS method employed for protein identification, the protein accession number of identified muscle proteins, Mascot scores, the number of matched peptide sequences, the percentage sequence coverage, the actual and theoretical molecular mass, the actual and theoretical pI-value, and fold change of individual proteins affected during muscle aging. Data sets from both $\mathrm{pH} 4$ 7 and pH 6-11 gels are combined in the list. The numbering of distinct 2-D spots of altered density shown in the 4 DIGE Cy5 master gels of Figs. 3 and 4 correlates with the 94 MS-identified protein species in Table 1. Overall a decreased expression level was shown for 35 protein spots and an increased concentration 


\section{DIGE Cy5 master gels of detergent-extracted fraction from gastrocnemius muscle}

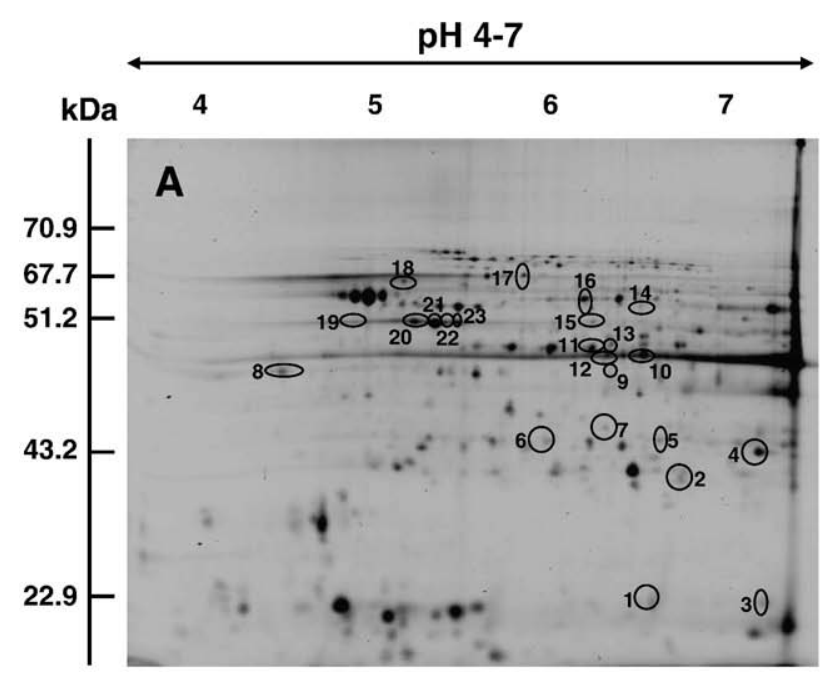

\begin{tabular}{rrrrrr}
$\longleftrightarrow$ & pH 6-11 \\
\hline 6 & 7 & 8 & 9 & 10 & 11
\end{tabular}

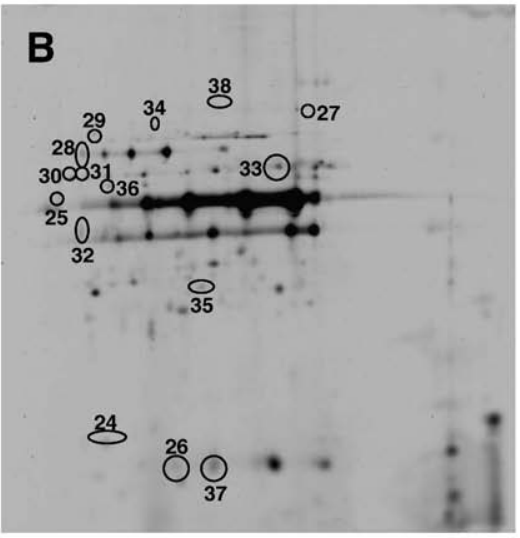

Fig. 3 - DIGE analysis of the detergent-extracted fraction from young adult versus old rat skeletal muscle. Shown are Cy5-labeled master gels of the detergent-extracted fraction from rat skeletal muscle, covering both the $\mathrm{pH}$ 4-7 (A) and $\mathrm{pH}$ 6-11 (B) range. Proteins with different expression levels are numbered 1 to 38 and are marked by circles. See Table 1 for a detailed listing of detergent-extracted proteins with a changed abundance in senescent fibres. The pH values of the IEF system and molecular mass standards (in $\mathrm{kDa}$ ) of the 2-DE gels are indicated on the top and on the left of the panels, respectively.

was found for 59 distinct protein species. Skeletal muscle proteins with an age-related change in abundance ranged in molecular mass from apparent $13.6 \mathrm{kDa}$ to $87.5 \mathrm{kDa}$ and covered a pI-range from approximately 4.7 to 9.2. In the DT fraction, protein species with increased expression levels were identified as Coq7 protein, ATP synthase, isocitrate dehydrogenase, enolase and tropomyosin. Interestingly, differential effects on dissimilar 2D spots representing the same protein or protein complex were observed for muscle creatine kinase, actin and prohibitin. Several unidentified proteins showed a reduced abundance in aged muscle. In the AQ fraction, proteins with an increased concentration were identified as cytosolic malate dehydrogenase, triosephosphate isomerase, bile salt sulfotransferase, PARK7 protein, HHIP-like protein 1, aldolase, pyruvate

\section{DIGE Cy5 master gels of aqueous fraction from gastrocnemius muscle}
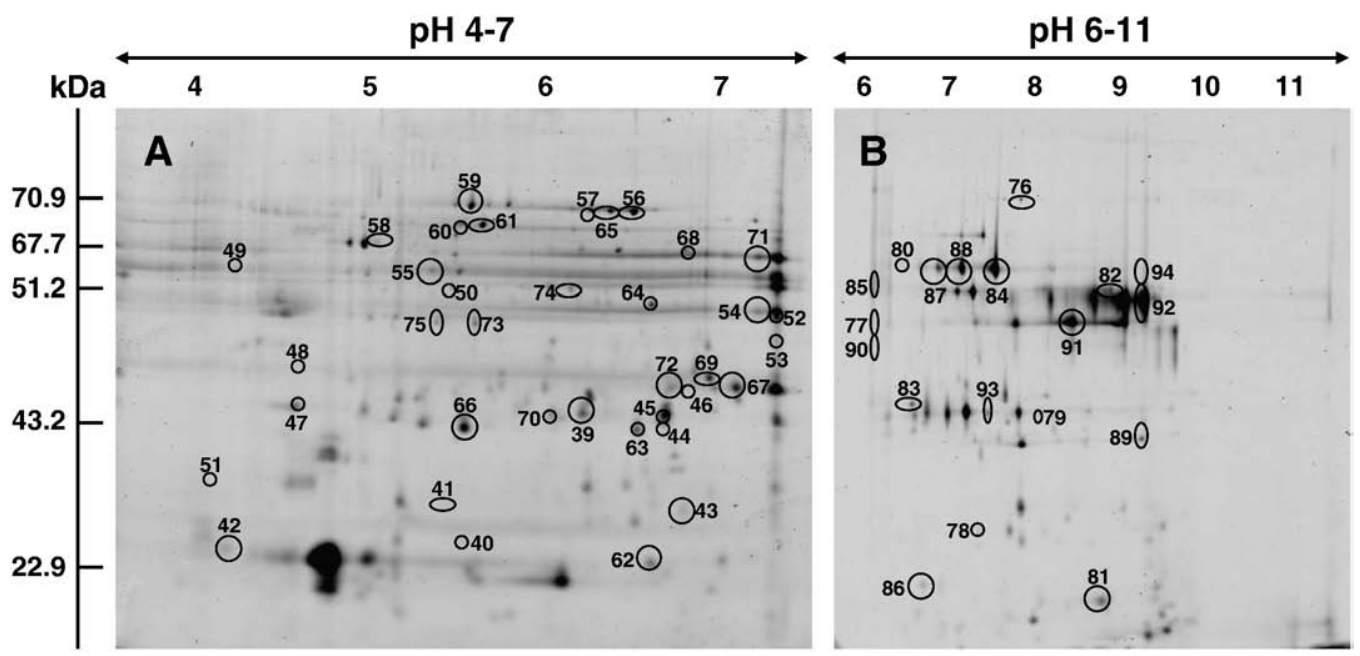

Fig. 4 - DIGE analysis of the aqueous fraction from young adult versus old rat skeletal muscle. Shown are Cy5-labeled master gels of the aqueous fraction from rat skeletal muscle, covering both the pH 4-7 (A) and pH 6-11 (B) range. Proteins with different expression levels are numbered 39 to 94 and marked by circles. See Table 1 for a detailed listing of aqueous phase-extracted proteins with a changed abundance in senescent fibres. The $\mathrm{pH}$ values of the IEF system and molecular mass standards (in $\mathrm{kDa}$ ) of the 2-DE gels are indicated on the top and on the left of the panels, respectively. 
Table 1 - DIGE-identified proteins with a changed abundance in the detergent (DT)-extracted and aqueous (AQ) fraction from young adult versus old rat gastrocnemius

muscle.

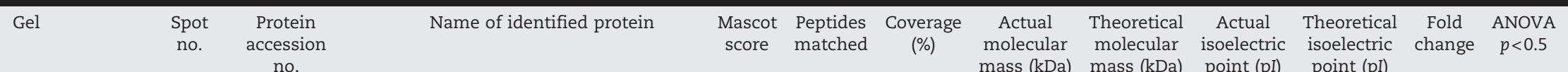

\begin{tabular}{|c|c|c|c|c|c|c|c|c|c|c|c|c|}
\hline \multirow[t]{23}{*}{ DT pH 4-7 ESI LC-MS/MS } & 1 & gi|149068153| & Demethyl-Q7 (Coq7) & 59 & 3 & 13 & 22.9 & 22.9 & 6.5 & 6.1 & +1.3 & 0.037 \\
\hline & 2 & gi|203055 & ATP synthase, alpha subunit & 363 & 14 & 23 & 39.0 & 58.9 & 6.8 & 9.2 & +1.5 & 0.032 \\
\hline & 3 & - & Unknown protein & - & - & - & 22.0 & - & 7.3 & - & -1.7 & 0.009 \\
\hline & 4 & gi|6978661| & Muscle creatine kinase & 82 & 5 & 14 & 43.2 & 43.2 & 7.2 & 6.6 & -1.5 & 0.03 \\
\hline & 5 & gi|6671762| & Muscle creatine kinase & 75 & 4 & 12 & 45.0 & 43.3 & 6.7 & 6.6 & +1.9 & 0.019 \\
\hline & 6 & gi|6679299| & Prohibitin & 337 & 18 & 74 & 45.0 & 29.9 & 6.0 & 5.6 & +1.4 & 0.002 \\
\hline & 7 & gi|6679299| & Prohibitin & 202 & 10 & 49 & 46.0 & 29.9 & 6.3 & 5.6 & -2.4 & 0.033 \\
\hline & 8 & gi|15778719| & Tropomyosin, alpha & 151 & 6 & 20 & 48.5 & 32.7 & 4.5 & 4.7 & +1.2 & 0.028 \\
\hline & 9 & gi|149049481| & Enolase 2, gamma isoform & 85 & 4 & 13 & 48.5 & 33.3 & 6.3 & 5.2 & +1.4 & 0.043 \\
\hline & 10 & gi|6679299| & Prohibitin & 168 & 5 & 34 & 49.5 & 29.9 & 6.5 & 5.6 & +2.1 & 0.037 \\
\hline & 11 & gi|16758446| & Isocitrate dehydrogenase 3 & 343 & 11 & 31 & 50.0 & 40.1 & 6.2 & 6.4 & +1.5 & 0.041 \\
\hline & 12 & gi|149041704| & Isocitrate dehydrogenase 3 & 350 & 17 & 36 & 49.5 & 39.4 & 6.3 & 5.9 & +1.5 & 0.022 \\
\hline & 13 & gi|16758446| & Isocitrate dehydrogenase 3 & 369 & 11 & 36 & 50.5 & 40.1 & 6.3 & 6.5 & +1.6 & 0.037 \\
\hline & 14 & gi|126723393| & Enolase 3, beta & 222 & 14 & 38 & 55.0 & 47.3 & 6.5 & 7.1 & +1.3 & 0.045 \\
\hline & 15 & gi|16758446| & Isocitrate dehydrogenase 3 & 156 & 6 & 24 & 51.0 & 40.1 & 6.2 & 6.5 & +1.2 & 0.016 \\
\hline & 16 & gi|6978661| & Muscle creatine kinase & 82 & 6 & 14 & 57.0 & 43.2 & 6.2 & 6.6 & +1.7 & 0.016 \\
\hline & 17 & gi|78365255| & Dihydro-lipoamide S-acetyltransferase & 160 & 11 & 21 & 67.7 & 67.7 & 5.9 & 8.8 & +1.1 & 0.032 \\
\hline & 18 & - & Unknown protein & - & - & - & 66.0 & - & 5.2 & - & -1.8 & 0.032 \\
\hline & 19 & - & Unknown protein & - & - & - & 51.0 & - & 4.9 & - & +1.4 & 0.033 \\
\hline & 20 & gi|1374715| & ATP synthase, beta subunit & 279 & 15 & 35 & 51.2 & 51.2 & 5.2 & 4.9 & +1.4 & 0.028 \\
\hline & 21 & gi|1374715| & ATP synthase, beta subunit & 196 & 12 & 34 & 51.2 & 51.2 & 5.3 & 4.9 & +1.4 & 0.011 \\
\hline & 22 & gi|157823033| & Actin, beta-2 & 76 & 6 & 15 & 51.0 & 42.3 & 5.4 & 5.3 & +1.4 & 0.02 \\
\hline & 23 & - & Unknown protein & & - & & 51.0 & - & 5.5 & - & +1.5 & 0.032 \\
\hline \multirow{15}{*}{ DT pH 6-11 ESI LC-MS/MS } & 24 & gi|149043182| & Actin, alpha-1 & 99 & 10 & 36 & 25.0 & 51.9 & 6.8 & 6.8 & -4.7 & 0.002 \\
\hline & 25 & - & Unknown protein & - & - & - & 49.0 & - & 6.2 & - & -2.4 & 0.033 \\
\hline & 26 & - & Unknown protein & - & - & - & 23.0 & - & 7.6 & - & -2.4 & 0.046 \\
\hline & 27 & gi|16758446| & Isocitrate dehydrogenase 3 & 63 & 3 & 11 & 69.0 & 40.1 & 9.1 & 6.5 & +2.4 & 0.044 \\
\hline & 28 & - & Unknown protein & - & - & - & 62.0 & - & 6.5 & - & -2.4 & 0.009 \\
\hline & 29 & - & Unknown protein & - & - & - & 68.0 & - & 6.6 & - & +2.4 & 0.02 \\
\hline & 30 & - & Unknown protein & - & - & - & 54.0 & - & 6.3 & - & -2.1 & 0.009 \\
\hline & 31 & gi|6978661| & Muscle creatine kinase & 50 & 4 & 10 & 54.0 & 43.2 & 6.5 & 6.6 & -1.9 & 0.043 \\
\hline & 32 & - & Unknown protein & - & - & - & 49.0 & - & 6.5 & - & -1.6 & 0.006 \\
\hline & 33 & - & Unknown protein & - & - & - & 57.0 & - & 8.8 & - & +1.4 & 0.04 \\
\hline & 34 & gi|126723393| & Enolase 3, beta & 276 & 24 & 40 & 68.5 & 47.3 & 7.3 & 7.1 & +1.4 & 0.018 \\
\hline & 35 & - & Unknown protein & - & - & - & 46.0 & - & 7.9 & - & -1.3 & 0.028 \\
\hline & 36 & - & Unknown protein & - & - & - & 51.0 & - & 6.8 & - & -1.2 & 0.046 \\
\hline & 37 & gi|126723393| & Enolase 3, beta & 114 & 4 & 17 & 23.0 & 47.3 & 8.0 & 7.1 & +2.5 & 0.074 \\
\hline & 38 & - & Unknown protein & - & - & - & 70.0 & - & 8.1 & - & +2.4 & 0.058 \\
\hline \multirow[t]{9}{*}{ AQ pH 4-7 ESI LC-MS/MS } & 39 & - & Unknown protein & - & - & - & 44.0 & - & 6.3 & - & -1.4 & 0.039 \\
\hline & 40 & - & Unknown protein & - & - & - & 25.5 & - & 5.6 & - & -1.7 & 0.017 \\
\hline & 41 & - & Unknown protein & - & - & - & 29.0 & - & 5.5 & - & -1.4 & 0.038 \\
\hline & 42 & gi|205474| & Myosin light chain & 143 & 6 & 36 & 25.0 & 20.9 & 4.1 & 5.0 & -1.7 & 0.03 \\
\hline & 43 & gi|1213217| & $\mathrm{Cu} / \mathrm{Zn}$ superoxide dismutase & 158 & 6 & 47 & 27.5 & 16.2 & 6.9 & 5.7 & -1.5 & 0.013 \\
\hline & 44 & gi|203658| & $\mathrm{Cu}-\mathrm{Zn}$ superoxide dismutase & 150 & 4 & 32 & 42.0 & 15.9 & 6.8 & 5.9 & +1.5 & 0.028 \\
\hline & 45 & gi|16924002| & Parkinson disease protein 7 & 88 & 13 & 74 & 44.0 & 20.2 & 6.8 & 6.3 & +1.5 & 0.017 \\
\hline & 46 & - & Unknown protein & - & - & - & 46.0 & - & 6.9 & - & +2.0 & 0.045 \\
\hline & 47 & gi|16924002| & Parkinson disease protein 7 & 116 & 6 & 56 & 45.0 & 20.2 & 4.6 & 6.3 & -1.2 & 0.025 \\
\hline
\end{tabular}




\begin{tabular}{|c|c|c|c|c|c|c|c|c|c|c|c|c|}
\hline & 48 & gi|9507245| & $\begin{array}{l}\text { Tyrosine 3-monooxygenase/tryptophan } \\
\text { 5-monooxygenase activation protein, } \\
\text { gamma subunit }\end{array}$ & 196 & 10 & 42 & 47.5 & 28.5 & 4.6 & 4.8 & -1.5 & 0.017 \\
\hline & 49 & gi|207349| & Tropomyosin, alpha & 261 & 19 & 49 & 62.0 & 32.7 & 4.1 & 4.7 & +1.5 & 0.019 \\
\hline & 50 & gi|55742832| & Annexin A4 & 282 & 10 & 35 & 51.0 & 36.2 & 5.5 & 5.4 & +1.4 & 0.004 \\
\hline & 51 & gi|37999910 & Annexin A4 & 161 & 6 & 26 & 32.0 & 36.2 & 4.0 & 5.3 & -1.6 & 0.028 \\
\hline & 52 & gi|38512111| & Triose phosphate isomerase Tpi1 & 71 & 7 & 33 & 49.5 & 27.2 & 7.3 & 7.1 & +1.3 & 0.048 \\
\hline & 53 & gi|38512111| & Triose phosphate isomerase Tpi1 & 141 & 8 & 52 & 48.0 & 27.2 & 7.4 & 7.1 & +1.4 & 0.013 \\
\hline & 54 & gi|38512111| & Triose phosphate isomerase Tpi1 & 177 & 11 & 62 & 50.0 & 27.2 & 7.3 & 7.1 & +1.2 & 0.042 \\
\hline & 55 & gii38512111| & Triose phosphate isomerase Tpi1 & 197 & 6 & 37 & 60.0 & 27.2 & 5.4 & 7.1 & +1.4 & 0.011 \\
\hline & 56 & gi|126723393| & Enolase 3, beta & 417 & 19 & 40 & 70.0 & 47.3 & 6.6 & 7.1 & +2.0 & 0.005 \\
\hline & 57 & gi|126723393| & Enolase 3, beta & 473 & 19 & 38 & 70.0 & 47.3 & 6.3 & 7.1 & +2.1 & 0.005 \\
\hline & 58 & gi|126723393| & Enolase 3, beta & 284 & 10 & 28 & 68.5 & 47.3 & 5.1 & 7.1 & -1.5 & 0.018 \\
\hline \multirow[t]{17}{*}{ AQ pH 4-7 MALDI-ToF/ToF MS } & 59 & HSP7C_RAT & Heat Shock Protein Hsp71 & 295 & 14 & 23 & 70.9 & 70.9 & 5.7 & 5.4 & -2.7 & 0.003 \\
\hline & 60 & ALBU_RAT & Serum Albumin & 182 & 15 & 30 & 69.0 & 68.7 & 5.6 & 6.1 & -2.2 & 0.016 \\
\hline & 61 & ALBU_RAT & Serum Albumin & 1070 & 23 & 48 & 69.0 & 68.7 & 5.8 & 6.1 & +2.1 & 0.022 \\
\hline & 62 & PGP_RAT & Phosphoglycolate phosphatase & 182 & 14 & 46 & 24.0 & 34.5 & 6.7 & 5.2 & -1.4 & 0.039 \\
\hline & 63 & ST2A 1_RAT & Bile salt sulfotransferase 1 & 180 & 3 & 17 & 42.0 & 33.2 & 6.6 & 7.7 & +2.0 & 0.022 \\
\hline & 64 & ENOB_RAT & Beta Enolase & 339 & 12 & 37 & 50.5 & 46.9 & 6.7 & 7.1 & +1.8 & 0.043 \\
\hline & 65 & HIPL1_RAT & HHIP-like protein 1 & 50 & 14 & 26 & 70.0 & 87.5 & 6.4 & 8.5 & +1.4 & 0.035 \\
\hline & 66 & PGP_RAT & Phospho glycolate phosphatase & 125 & 7 & 26 & 43.0 & 34.5 & 5.6 & 5.2 & +1.4 & 0.048 \\
\hline & 67 & IDH3A_RAT & $\begin{array}{l}\text { Isocitrate dehydrogenase (NAD) subunit } \\
\text { alpha, mitochondrial }\end{array}$ & 100 & 4 & 12 & 46.5 & 39.6 & 7.2 & 6.5 & -1.8 & 0.010 \\
\hline & 68 & ODP2_RAT & $\begin{array}{l}\text { Dihydrolipoyl lysine-residue } \\
\text { acetyltransferase pyruvate dehydrogenase }\end{array}$ & 158 & 9 & 18 & 67.0 & 67.1 & 6.9 & 8.8 & -2.4 & 0.023 \\
\hline & 69 & IDH3A_RAT & $\begin{array}{l}\text { Isocitrate dehydrogenase (NAD) subunit } \\
\text { alpha, mitochondrial }\end{array}$ & 363 & 10 & 26 & 47.0 & 39.6 & 7.0 & 6.5 & +1.6 & 0.048 \\
\hline & 70 & LDHB_RAT & Lactate dehydrogenase B Chain & 59 & 10 & 26 & 44.0 & 36.6 & 6.1 & 5.7 & +1.8 & 0.014 \\
\hline & 71 & Z354C_RAT & Zinc Finger Protein & 62 & 9 & 23 & 67.0 & 64.2 & 7.3 & 8.6 & -2.2 & 0.038 \\
\hline & 72 & MDHC_RAT & Malate dehydrogenase & 64 & 2 & 8 & 46.5 & 36.5 & 6.8 & 6.2 & +2.1 & 0.019 \\
\hline & 73 & CSN4_RAT & COP9 signalosome complex subunit 4 & 279 & 9 & 31 & 49.0 & 46.3 & 5.7 & 5.6 & -1.8 & 0.021 \\
\hline & 74 & CH60_RAT & $60 \mathrm{kDa}$ heat shock protein mitochondrial & 599 & 15 & 35 & 51.0 & 60.9 & 6.2 & 5.9 & -2.6 & 0.003 \\
\hline & 75 & ENOB_RAT & Gamma enolase & 169 & 11 & 40 & 49.0 & 47.1 & 5.4 & 5.0 & -2.1 & 0.005 \\
\hline \multirow[t]{19}{*}{ AQ pH 6-11 ESI LC-MS/MS } & 76 & - & Unknown protein & - & - & - & 71.0 & - & 7.9 & - & +3.1 & 0.009 \\
\hline & 77 & gi|126723393| & Enolase 3, beta & 314 & 15 & 36 & 49.0 & 47.3 & 6.1 & 7.1 & +2.3 & 0.012 \\
\hline & 78 & gi|55926145| & Nucleoside diphosphate kinase B & 77 & 7 & 51 & 26.0 & 17.4 & 7.2 & 6.9 & -1.9 & 0.041 \\
\hline & 79 & - & Unknown protein & - & - & - & 44.0 & - & 8.0 & - & +1.7 & 0.005 \\
\hline & 80 & gi|149041703| & Isocitrate dehydrogenase 3 & 81 & 2 & 11 & 62.0 & 30.9 & 6.4 & 6.0 & +1.7 & 0.016 \\
\hline & 81 & - & Unknown protein & - & - & - & 21.0 & - & 8.8 & - & -1.6 & 0.013 \\
\hline & 82 & gi|126723393| & Enolase 3, beta & 122 & 7 & 20 & 51.0 & 47.3 & 8.9 & 7.1 & +1.6 & 0.009 \\
\hline & 83 & - & Unknown protein & - & - & - & 44.5 & - & 6.5 & - & +1.5 & 0.034 \\
\hline & 84 & gi|16757994| & Pyruvate kinase, muscle & 130 & 8 & 20 & 61.0 & 58.3 & 7.5 & 6.6 & +1.5 & 0.024 \\
\hline & 85 & gi|109488172| & Cofilin-2 & 90 & 2 & 25 & 57.0 & 13.6 & 6.1 & 8.9 & +1.5 & 0.004 \\
\hline & 86 & & Unknown protein & - & - & - & 22.0 & - & 6.7 & - & -1.5 & 0.028 \\
\hline & 87 & gi|16757994| & Pyruvate kinase, muscle & 66 & 10 & 28 & 61.0 & 58.3 & 6.9 & 6.6 & +1.5 & 0.024 \\
\hline & 88 & gi|117935064| & Triose phosphate isomerase Tpi1 & 195 & 8 & 41 & 61.0 & 27.4 & 7.1 & 6.9 & +1.4 & 0.03 \\
\hline & 89 & - & Unknown protein & - & - & - & 41.0 & - & 9.2 & - & +1.4 & 0.032 \\
\hline & 90 & gi|6978491| & Aldo-keto reductase family $1, \mathrm{~B} 1$ & 46 & 7 & 16 & 48.0 & 36.2 & 6.1 & 6.3 & -1.4 & 0.005 \\
\hline & 91 & gi|16757994| & Pyruvate kinase, muscle & 174 & 6 & 15 & 49.0 & 58.3 & 8.4 & 6.6 & +1.3 & 0.041 \\
\hline & 92 & gi|149067838| & Aldolase A & 49 & 4 & 10 & 50.0 & 36.4 & 9.2 & 8.5 & +1.3 & 0.038 \\
\hline & 93 & gi|38512111| & Triose phosphate isomerase Tpi1 & 241 & 12 & 62 & 44.0 & 27.2 & 7.5 & 7.1 & +1.2 & 0.043 \\
\hline & 94 & gi|16757994| & Pyruvate kinase, muscle & 343 & 13 & 32 & 60.5 & 58.3 & 9.2 & 6.6 & +1.2 & 0.026 \\
\hline
\end{tabular}


kinase, cofilin-2 and lactate dehydrogenase. Differential effects on dissimilar 2D spots of the same protein species were shown for $\mathrm{Cu} / \mathrm{Zn}$ superoxide dismutase, albumin, enolase, isocitrate dehydrogenase, annexin A4, and phosphoglycolate phosphatase. COP9 signalosome complex subunit 4, Hsp71, mitochondrial Hsp60, tyrosine 3-monooxygenase/tryptophan 5monooxygenase activation protein, dihydrolipoyllysine-residue acetyltransferase of the pyruvate dehydrogenase complex, zink finger protein, nucleoside diphosphate kinase B, myosin light chain and aldo-keto reductase exhibited a reduced density in aged muscle. The majority of identified proteins were found to be involved in mitochondrial metabolism, glycolysis, metabolic transportation, regulatory processes, the cellular stress response, detoxification mechanisms and contraction.

3.5. Immunoblot analysis of age-related changes in the skeletal muscle proteome

Based on the above shown immunoblotting of abundant markers of the soluble and detergent-extracted cohort of muscle proteins (Fig. 1C-E), a similar immunodecoration analysis was used to validate representative findings from the DIGE analysis of young adult versus aged muscle tissue. Western blotting revealed comparable levels of the peripheral protein isoform CSQf of the $\mathrm{Ca}^{2+}$-binding protein calsequestrin in the AQ phase, as well as similar levels of the integral $\mathrm{Ca}^{2+}$-ATPase and the stress protein Hsp25 in the DT phase of 3-month versus 26-month old gastrocnemius muscle (Fig. 5A-C). This demonstrates equal loading of these unaltered proteins during the electrophoretic separation protocol. In contrast to these muscle proteins, and in agreement with the DIGE analysis presented here and in previous proteomic studies [13], ATP synthase, succinate dehydrogenase, prohibitin and malate dehydrogenase were significantly increased in aged preparations (Fig. 5D-G). The statistical evaluation is shown for age-related expression changes in ATP synthase, succinate dehydrogenase and malate dehydrogenase (Fig. 5H-J).

\section{Discussion}

The human genome is estimated to contain 25,000 genes of which approximately $30 \%$ encode for membrane-associated
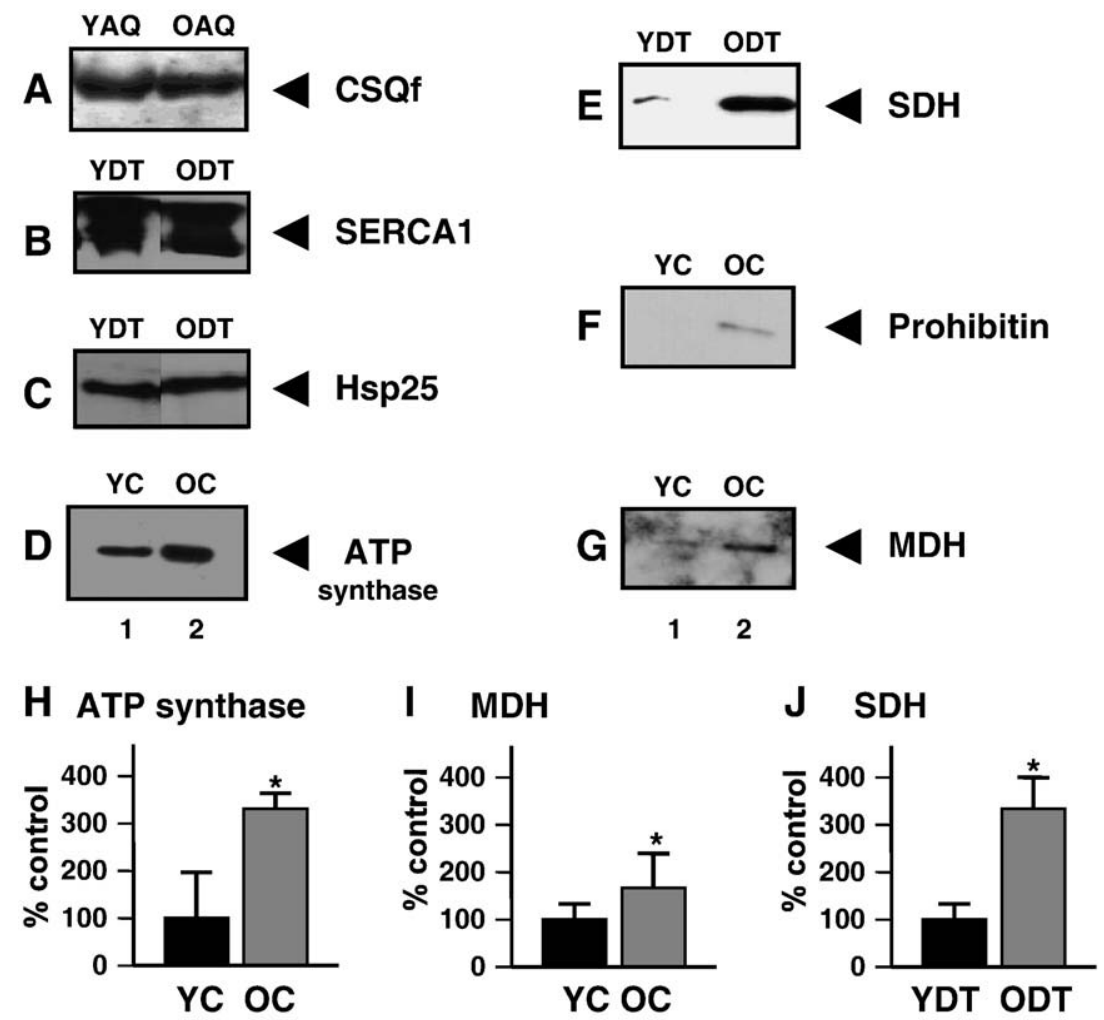

Fig. 5 - Immunoblot analysis of the subcellular fractionation of the aqueous versus the detergent-extracted fraction from skeletal muscle tissue. Shown are expanded views of immuno-decorated bands of the fast CSQf isoform of calsequestrin (A), $\mathrm{Ca}^{2+}$-ATPase isoform SERCA1 (B), heat shock protein Hsp25 (C), mitochondrial ATP synthase (D), succinate dehydrogenase (SDH) (E), prohibitin (F) and malate dehydrogenase (MDH) (G), respectively. The different fractions analyzed represent crude preparations from young muscle (YC), crude preparations from old muscle (OC), aqueous phase-enriched proteins from young muscle (YAQ), aqueous phase-enriched proteins from old muscle (OAQ), detergent phase-enriched proteins from young muscle (YDT) and detergent phase-enriched proteins from old muscle (ODT). The general protein expression pattern of the analyzed fractions corresponds with the fractions shown in the silver-stained 1D gel of Fig. 1B. Significant changes in abundance were found for mitochondrial ATP synthase, MDH and SDH, as documented in the graphical presentation of the statistical evaluation of antibody labeling in panels $(\mathrm{H})$ to $(\mathrm{J})$. The comparative blotting was statistically evaluated using an unpaired Student's t-test $\left(n=5 ;{ }^{*} p<0.05\right)$. Lanes 1 and 2 represent protein fractions from 3-month versus 26-month old skeletal muscle fibres, respectively. $30 \mu \mathrm{g}$ of protein was loaded per lane per sample for all immunoblots. 
proteins [34]. Integral proteins are both of fundamental biological importance and represent crucial therapeutic targets [35], giving central importance to the identification of their role in aging. However, to date skeletal muscle proteome studies have mostly investigated soluble proteins thereby underestimating altered expression levels of integral elements. In contrast to the proteome-wide analysis of total tissue extracts, the subproteomic profiling of distinct subsets of proteins usually provides a reduction in sample complexity [36]. This can be advantageous for the identification of lowabundance signature molecules. With respect to muscle proteomics, the mass spectrometry-based profiling of crude muscle extracts has decisively advanced basic and applied myology $[13,37,38]$, but a major limitation of current proteomic platforms is their limited dynamic range for resolving complex protein complements. Crude extract proteomics is therefore unable to reveal the complete proteome complexity of whole skeletal muscles. Recently, major advances have been made in the proteomic profiling of large cellular structures, organelles and membrane domains from diverse tissue systems [39-41]. Thus, to further advance the analytical capabilities of skeletal muscle proteomics, the establishment of reproducible sample fractionation methods that circumvent the introduction of artifacts is essential in order to enrich membrane-associated proteins present in muscle fibres.

Here, we have successfully applied a nonionic detergent phase extraction method for the analysis of the aqueous versus the membrane-associated fraction from skeletal muscle homogenates. Immunoblotting verified the enrichment of integral membrane proteins in the detergent-extracted fraction and demonstrated increased expression levels of key marker proteins in aged muscle, such as prohibitin. Following separation by standard 2-DE, the abundance of key mitochondrial markers, such as ATP synthase and isocitrate dehydrogenase, was increased in the DT fraction. This would agree with an age-related shift to more oxidative metabolism in a slower-twitching fibre population [13-15]. Differential effects on individual protein spots representing muscle creatine kinase and prohibitin indicate altered post-translational modifications, such as phosphorylation patterns, in these proteins during muscle aging [42]. A variety of muscle proteins in the aqueous phase showed varying degrees of alterations in young adult versus aged muscle, making interpretations on their role in senescence difficult. However, the increase in malate dehydrogenase, triosephosphate isomerase, sulfotransferase, aldolase, and lactate dehydrogenase in aged muscle, and the decrease in zink finger protein, nucleoside diphosphate kinase B and the two stress proteins Hsp71 and mtHsp60 could be useful for the future establishment of a biomarker signature of sarcopenia of old age. Identified muscle proteins with an age-related change in abundance were shown to be constituents of glycolysis, metabolic transportation, mitochondrial metabolism, cellular regulation, the stress response, detoxification mechanisms and fibre contraction.

The slight increase of low-abundance isoforms of pyruvate kinase in the aqueous phase is an interesting finding, since previous studies on crude total extracts have shown a decrease of one of the major sub-species of this glycolytic enzyme [18]. Pyruvate isoform PK-M1 exists as 5 sub-species with differing isoelectric points in skeletal muscle tissues, whereby theses isozymes display varying degrees of phosphorylation and glycosylation [21,24]. Previous studies have clearly shown that the PK isoform exhibiting a pI of 6.6 and an apparent molecular mass of $57.8 \mathrm{kDa}$ is several-fold decreased in senescent muscle fibres [21]. Other PK forms with a more acidic or basic pI-value did not show major alterations in concentration levels between crude total protein extracts from young versus aged muscle [18]. In contrast, the PK isoforms identified in this study by MS analysis show pI-values of approximately 6.9, 7.5, 8.4 and 9.2. They therefore represent different sub-species of pyruvate kinase, as compared to the major protein previously shown to be reduced during aging. These findings highlight the potential problems with interpreting proteomic data on protein isoforms that exist as several sub-species in individual tissues. In addition, a large number of muscle proteins do not exhibit a linear relationship between molecular mass and their electrophoretic mobility. This complicates both the internal analysis of protein expression patterns and the comparison between different proteomic studies. As can be seen in Table 1, considerable differences can be detected between the actual and the theoretical molecular mass of a number of identified proteins. The same was found in the case of actual and theoretical pI-values. The reasons for these apparent discrepancies are that individual 2D spots may represent degradation products of a larger protein, aggregates that do not disintegrate during gel electrophoresis and/or proteins with extensive post-translational modifications.

The proteomic findings presented here suggest that muscle aging is associated with a generally perturbed protein expression pattern that affects especially metabolic pathways. Most physiological and histological studies of fibre aging indicate that sarcopenia is due to a multi-factorial pathology. Skeletal muscle aging is associated with a wide variety of cellular, biochemical and physiological alterations, including (i) grouped atrophying fibres, increased numbers of centrally located nuclei and variability in fibre diameter [9], (ii) metabolic alterations [43], (iii) mitochondrial disturbances and an increased susceptibility to apoptosis [44], (iv) a decreased regenerative capacity [45], (v) disturbed luminal ion binding and cycling [46], (vi) excitation-contraction uncoupling [47], (vii) oxidative stress [48], (viii) a blunted cellular stress response [49], (ix) impaired protein synthesis of myofibrillar components [50], ( (x) denervation-associated atrophy [51], (xi) an altered equilibrium of growth factors and hormones involved in fibre maintenance [52], and (xii) a severe decline in contractile efficiency [53]. Our proteomic map of alterations in protein expression in the aqueous versus detergent-extracted fractions from aged muscle agrees with the idea of complex biochemical changes in sarcopenia. The experimental strategy that the subproteomic analysis of distinct fractions affords a reduction in sample complexity, thereby potentially revealing novel biomarkers of muscle aging and impaired muscle function that would otherwise remain undiscovered, has been substantiated in this report. As compared to previous whole-proteome investigations [13], this study has identified novel low-abundance muscle proteins with a changed abundance during muscle aging, such as Coq7 protein, sulfotransferase, PARK7 protein, HHIP-like protein 1, zink finger protein, nucleoside diphosphate kinase 
$B$, aldo-keto reductase and COP9 signalosome complex subunit 4. The separation of the highly soluble protein complement from the detergent-extractable protein cohort has resulted in the enrichment of new biomarker candidates in both the aqueous and the membrane-associated fractions from muscle homogenates. The detailed biochemical and cell biological characterization of these potential signature molecules should help in the establishment of a comprehensive biomarker collection for sarcopenia-related cellular abnormalities. In the long term, established alterations in these marker proteins will be useful for improving diagnostic methods, the identification of novel therapeutic targets and the monitoring of experimental treatments to halt or reverse age-associated fibre wasting.

\section{Acknowledgements}

Research was supported by a principal investigator grant from Science Foundation Ireland (SFI-04/IN3/B614) and equipment grants from the Irish Health Research Board and the Irish Higher Education Authority (HRB-EQ/2003/3, HEA-RERGS-07NUIM, HRB-EQ/2004/2). The authors thank Dr. Marina Lynch (Trinity College Dublin) for her generous help obtaining aged rat muscle, and Ms. Caroline Batchlor (NUI Maynooth) for her assistance with mass spectrometry.

\section{REFER E N C E S}

[1] Vijg J, Campisi J. Puzzles, promises and a cure for ageing. Nature 2008;454:1065-71.

[2] Thompson LV. Age-related muscle dysfunction. Exp Gerontol 2009;44:106-11.

[3] Vandervoort AA. Aging of the human neuromuscular system. Muscle Nerve 2002;25:17-25.

[4] Greenlund LJS, Nair KS. Sarcopenia-consequences, mechanisms, and potential therapies. Mech Ageing Dev 2003;124:287-99.

[5] Doherty TJ. Aging and sarcopenia. J Appl Physiol 2003;95:1717-27.

[6] Rolland Y, Czerwinski S, Abellan Van Kan G, Morley JE, Cesari M, Onder G, Woo J, Baumgartner R, Pillard F, Boirie Y, Chumlea WM, Vellas B. Sarcopenia: its assessment, etiology, pathogenesis, consequences and future perspectives. J Nutr Health Aging 2008;12:433-50.

[7] Frontera WR, Reid KF, Phillips EM, Krivickas LS, Hughes VA, Roubenoff R, Fielding RA. Muscle fiber size and function in elderly humans: a longitudinal study. J Appl Physiol 2008;105: 637-42.

[8] Faulkner JA, Larkin LM, Claflin DR, Brooks SV. Age-related changes in the structure and function of skeletal muscles. Clin Exp Pharmacol Physiol 2007;34:1091-6.

[9] Edstrom E, Altun M, Bergman E, Johnson H, Kullberg S, Ramirez-Leon V, Ulfhake B. Factors contributing to neuromuscular impairment and sarcopenia during aging. Physiol Behav 2007;92:129-35.

[10] Baumgartner RN, Stauber PM, McHugh D, Koehler KM, Garry PJ. Cross-sectional age differences in body composition in persons 60+ years of age. J Gerontol A Biol Sci Med Sci 1995;50:M307-16.

[11] Lindle RS, Metter EJ, Lynch NA, Fleg JL, Fozard JL, Tobin J, Roy TA, Hurley BF. Age and gender comparisons of muscle strength in 654 women and men aged 20-93 yr. J Appl Physiol 1997;83:1581-7.
[12] Janssen I, Heymsfield SB, Ross R. Low relative skeletal muscle mass (sarcopenia) in older persons is associated with functional impairment and physical disability. J Am Geriatr Soc 2002;50:889-96.

[13] Doran P, Donoghue P, O'Connell K, Gannon J, Ohlendieck K. Proteomics of skeletal muscle aging. Proteomics 2009;9:989-1003.

[14] Piec I, Listrat A, Alliot J, Chambon C, Taylor RG, Bechet D. Differential proteome analysis of aging in rat skeletal muscle. FASEB J 2005;19:1143-5.

[15] Gelfi C, Vigano A, Ripamonti M, Pontoglio A, Begum S, Pellegrino MA, Grassi B, Bottinelli R, Wait R, Cerretelli P. The human muscle proteome in aging. J Proteome Res 2006;5: 1344-53.

[16] O’Connell K, Gannon J, Doran P, Ohlendieck K. Proteomic profiling reveals a severely perturbed protein expression pattern in aged skeletal muscle. Int J Mol Med 2007;20:145-53.

[17] Doran P, Gannon J, O'Connell K, Ohlendieck K. Aging skeletal muscle shows a drastic increase in the small heat shock proteins $\alpha$ B-crystallin/HspB5 and cvHsp/HspB7. Eur J Cell Biol 2007;86:629-40.

[18] Doran P, O'Connell K, Gannon J, Kavanagh M, Ohlendieck K. Opposite pathobiochemical fate of pyruvate kinase and adenylate kinase in aged rat skeletal muscle as revealed by proteomic DIGE analysis. Proteomics 2008;8:364-77.

[19] Capitanio D, Vasso M, Fania C, Moriggi M, Vigano A, Procacci P, Magnaghi V, Gelfi C. Comparative proteomic profile of rat sciatic nerve and gastrocnemius muscle tissues in ageing by 2-D DIGE. Proteomics 2009;9:2004-20.

[20] Lombardi A, Silvestri E, Cioffi F, Senese R, Lanni A, Goglia F, de Lange $\mathrm{P}$, Moreno M. Defining the transcriptomic and proteomic profiles of rat ageing skeletal muscle by the use of a cDNA array, 2D- and Blue native-PAGE approach. J Proteomics 2009;72:708-21.

[21] O'Connell K, Doran P, Gannon J, Ohlendieck K. Lectin-based proteomic profiling of aged skeletal muscle: decreased pyruvate kinase isozyme M1 exhibits drastically increased levels of N-glycosylation. Eur J Cell Biol 2008;87:793-805.

[22] O'Connell K, Ohlendieck K. Proteomic DIGE analysis of the mitochondria-enriched fraction from aged rat skeletal muscle. Proteomics 2009;9:5509-24.

[23] Gannon J, Doran P, Kirwan A, Ohlendieck K. Drastic increase of myosin light chain MLC-2 in senescent skeletal muscle indicates fast-to-slow fibre transition in sarcopenia of old age. Eur J Cell Biol 2009;88:685-700.

[24] Gannon J, Staunton L, O'Connell K, Doran P, Ohlendieck K. Phosphoproteomic analysis of aged skeletal muscle. Int J Mol Med 2008;22:33-42.

[25] Kanski J, Hong SJ, Schoneich C. Proteomic analysis of protein nitration in aging skeletal muscle and identification of nitrotyrosine-containing sequences in vivo by nanoelectrospray ionization tandem mass spectrometry. J Biol Chem 2005;280:24261-6.

[26] Bordier C. Phase separation of integral membrane proteins in Triton X-114 solution. J Biol Chem 1981;256:1604-7.

[27] Donoghue PM, Hughes C, Vissers JPC, Langridge JI, Dunn MJ. Non-ionic detergent phase extraction for the proteomic analysis of heart membrane proteins using label-free LC-MS. Proteomics 2008;8:3895-905.

[28] Viswanathan S, Unlu M, Minden JS. Two-dimensional difference gel electrophoresis. Nat Protoc 2006;1:1351-8.

[29] Bradford MM. A rapid and sensitive method for the quantitation of microgram quantities of protein utilizing the principle of protein-dye binding. Anal Biochem 1976;72:248-54.

[30] Donoghue P, Doran P, Wynne K, Pedersen K, Dunn MJ, Ohlendieck K. Proteomic profiling of chronic low-frequency stimulated fast muscle. Proteomics 2007;7:3417-30.

[31] Karp NA, Lilley KS. Maximising sensitivity for detecting changes in protein expression: experimental design using minimal CyDyes. Proteomics 2005;5:3105-15. 
[32] Karp NA, McCormick PS, Russell MR, Lilley KS. Experimental and statistical considerations to avoid false conclusions in proteomics studies using differential in-gel electrophoresis. Mol Cell Proteomics 2007;6:1354-64.

[33] Kane LA, Yung CK, Agnetti G, Neverova I, Van Eyk JE. Optimization of paper bridge loading for 2-DE analysis in the basic $\mathrm{pH}$ region: application to the mitochondrial subproteome. Proteomics 2006;6:5683-7.

[34] Stevens TJ, Arkin IT. Do more complex organisms have a greater proportion of membrane proteins in their genomes? Proteins 2000;39:417-22.

[35] Hopkins AL, Groom CR. The druggable genome. Nat Rev Drug Discov 2002;1:727-30.

[36] Gauthier DJ, Lazure C. Complementary methods to assist subcellular fractionation in organellar proteomics. Expert Rev Proteomics 2008;5:603-17.

[37] Isfort RJ. Proteomic analysis of striated muscle. J Chromatogr 2002;B771:155-65.

[38] Doran P, Gannon J, O'Connell K, Ohlendieck K. Proteomic profiling of animal models mimicking skeletal muscle disorders. Proteomics Clin Appl 2007;1:1169-84.

[39] Zheng YZ, Foster LJ. Biochemical and proteomic approaches for the study of membrane microdomains. J Proteomics 2009;72:12-22.

[40] Tan S, Tan HT, Chung MC. Membrane proteins and membrane proteomics. Proteomics 2008;8:3924-32.

[41] Sadowski PG, Groen AJ, Dupree P, Lilley KS. Sub-cellular localization of membrane proteins. Proteomics 2008;8: 3991-4011.

[42] Schoneich C. Protein modification in aging: an update. Exp Gerontol 2006;41:807-12.

[43] Vandervoort AA, Symons TB. Functional and metabolic consequences of sarcopenia. Can J Appl Physiol 2001;26:90-101.
[44] Chabi B, Ljubicic V, Menzies KJ, Huang JH, Saleem A, Hood DA. Mitochondrial function and apoptotic susceptibility in aging skeletal muscle. Aging Cell 2008;7:2-12.

[45] Lorenzon P, Bandi E, de Guarrini F, Pietrangelo T, Schaefer R, Zweyer M, Wernig A, Ruzzier F. Ageing affects the differentiation potential of human myoblasts. Exp Gerontol 2004;39:1545-54.

[46] O'Connell K, Gannon J, Doran P, Ohlendieck K. Reduced expression of sarcalumenin and related $\mathrm{Ca}^{2+}$-regulatory proteins in aged rat skeletal muscle. Exp Gerontol 2008;43: 958-61.

[47] Delbono O, O'Rourke KS, Ettinger WH. Excitation-calcium release uncoupling in aged single human skeletal muscle fibers. J Membr Biol 1995;148:211-22.

[48] Squier TS, Bigelow DJ. Protein oxidation and age-dependent alterations in calcium homeostasis. Front Biosci 2000;5: 504-26.

[49] Kayani AC, Morton JP, McArdle A. The exercise-induced stress response in skeletal muscle: failure during aging. Appl Physiol Nutr Metab 2008;33:1033-41.

[50] Balagopal P, Rooyackers OE, Adey DB, Ades PA, Nair KS. Effects of aging on in vivo synthesis of skeletal muscle myosin heavy-chain and sarcoplasmic protein in humans. Am J Physiol 1997;273:E790-800.

[51] Jackman RW, Kandarian SC. The molecular basis of skeletal muscle atrophy. Am J Physiol Cell Physiol 2004;287:C834-43.

[52] Lee CE, McArdle A, Griffiths RD. The role of hormones, cytokines and heat shock proteins during age-related muscle loss. Clin Nutr 2007;26:524-34.

[53] Prochniewicz E, Thompson LV, Thomas DD. Age-related decline in actomyosin structure and function. Exp Gerontol 2007;42:931-8. 